\title{
The New Bank Capital Adequacy Standards
}

\author{
R. Alton Gilbert, Courtenay C. Stone and Michael E. Trebing
}

翟彎 mercial banks - the Federal Deposit Insurance Corporation (FDIC), Federal Reserve (FED) and Office of the Comptrollee of the Currency $10 \mathrm{CC}$ - recently adopted new capital adequacy standards for bank supervision and regulation purposes. 'The new mini" mum standards are 5.5 percent for the ratio of primary capital to total assets and 6 percent for the ratio of total capital to total assets. ${ }^{2}$ In general, the new standards increase the minimum capital requirements for larger banks, while reducing them for smaller banks.

There are two reasons for the change in bank capital standards. First, the relatively large number of bank failures in recent years has become a matter of considerable public concern." While bank failures averaged only 10 per year as recently as 1979 through 1981 , the number of bank failures reached 79 in 1984. Twenty nine banks failed in the first four months of 1985 , and there are expectations that the number of failures during 1985 will equal or surpass that in 1984.4 Many

R. Alton Gibert is an assistant vice president, Courtenay C. Stone is a senior economist, and Michael $E$. Trebing is a research officer at the Federal Reserve Bank of St. Louis. Michael L. Durbin and Jude L. Naes, Jr., provided research assistance.

'The FDIC is the primary supervisory authority at the federal level for FDIC-insured, state-chartered banks that are not members of the FED. The FED supervises FDIC-insured, state-chartered member banks and regulates bank holding companies. The OCC supervises banks with national charters; these national banks are $\mathrm{FDIC}$-insured and members of the Federal Reserve System.

2The FED has also announced new capital standards for bank holding companies (BHCs). The minimum ratios for primary and total capital tor BHCs are the same as those for banks; however, there are differences in the tems that are included in primary and secondary capital. This article does not analyze the effect of the new captal requirements on BHCs.

3For survey data showing public concern about the stability of the banking system, see Gross (1984), Blundell (1985) and "Bank Crisis Tied. .." (1985). For predictions of more bank falures, see "More Bank Fallures. .." (1985) and Belsie (1985). Finally, for some comments on the political consequences of bank failures, see "Banking Confidence May. . " (1985).

${ }^{4}$ For one estimate of the number of banks that will fail in 1985, see "Agriculture: FDIC Study Says. .." (1985). people, including bank regulators, believe that higher bank capital ratios will reduce the number of bank failures that otherwise would occur."

Second, the International Lending and Supervision Act of 1983 specifies, in part, that each "appropriate Federal Banking Agency shall cause banking institutions to achieve and maintain adequate capital by establishing minimum levels of capital." The changes in bank capital standards are intended to address the public and congressional concern about the adequacy of bank capital.

This article describes the new bank capital standards and estimates their potential impact on the U.S. banking industry, using data from the December 31 , 1984, Report of Condition for U.S. commercial banks. In general, meeting the new standards will produce relatively small changes for the banking industry. Only 419 of the 14,404 banks surveyed have capital ratios below the new standards. These capital-deficient banks must raise about $\$ 1.8$ billion in capital, which represents a capital increase of about 7 percent for the deficient banks but only about 1 percent for the industry as a whole

This article also examines the potential changes in capital and assets that the banking system would face if minimum capital ratios were raised to the higher levels recently suggested by a Treasury Department study group and the FDIC. The analysis suggests that the 9 percent capital-to-asset standard currently un-

\footnotetext{
${ }^{5}$ There is remarkably little evidence, however, that links the level of capital or the ratio of capital to assets with bank failure rates. For example, a regulatory impact study prepared by the OCC notes, "It is impossible to say how many bank failures will be avoided as a result of the [new capital] rule, how many there would have been if the rule had been in effect eartier, or the effect on the failure rate of other minimum ratios" (Office of the Comptroller of the Currency (1985)). In an appendix to the FDIC's report to Congress in 1983, four bank falture prediction studies were reviewed; none of them found bank capital ratios, as measured in the current regutations, to be of major importance in discriminating between failed and successful banks (Federal Deposit Insurance Corporation (1983)).
} 
der discussion would require considerable changes for the U.S. banking system. At the present time the banking system, in the aggregate, has a total capital/ asset ratio of slightly more than 7 percent. If the 9 percent standard were adopted, more than half of all U.S. commercial banks would be deficient. To meet the suggested 9 percent standard, the deficient banks would have to raise about $\$ 52$ billion in new capital or reduce their assets (and liabilities) by nearly $\$ 523$ billion. Thus, either the capital of U.S. commercial banks would have to rise by about 29 percent or the U.S. banking industry would have to "shrink" its assets by more than one-fifth.

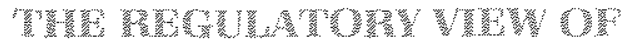

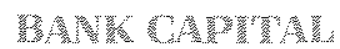

In general terms, bank regulators define a bank's capital as the difference between the book value of its assets and liabilities. Bank regulators view capital as performing several important roles. It provides a financial "cushion" that enables banks to continue to operate even if they are temporarily sustaining losses. It is presumed to maintain public confidence in the soundness of individual banks and the banking system as a whole. And it is alleged to provide some degree of protection to depositors whose bank accounts are nof fully insured.

Federal bank regulators divide bank capital into two categories: primary and secondary. The specific balance sheet items that constitute bank capital for regulatory purposes are presented in table 1.

Primary capital consists of the initial investment of shareholders, retained earnings and capital reserves set up to absorb possible future losses. Secondary capital consists of the sum of limited-life preferred stock, subordinated notes and debentures and certain other items isee table 1). Each bank's secondary capital is added to its primary capital to obtain its total capital for regulatory purposes. The regulatory agencies limit the amount of secondary capital included in total capital to no more than 50 percent of a bank's primary capital.

Regulators include subordinated long-term debt as

"This view of capital is ofien referred to as the "accounting" definition of capital. In contrast, the "economic" definition of bank capital focuses on the market value (or net present value) of the bank. These two definitions yield identical values only if all assets (inciuding "good will") and liabilities are carried on the bank's balance sheets at their current market values. In general, however, many bank assets, liabilities and capital account items are valued on a historical basis rather than at current market values. part of capital for two reasons: these debt instruments must have initial average weighted maturities of at least seven years, and, should the bank fail, investors in these debt instruments receive payment only after all depositors have received full payment.

Federal regulatory agencies, however, do not view subordinated long-term debt as equivalent to primary capital in determining the capital adequacy of banks; consequently, they impose certain limits on the extent to which it is counted as capital. If a bank experiences a major reduction in the value of its assets, primary capital provides a better buffer against bankruptcy than secondary capital. While dividends to shareholders can be cut to zero to maintain capital, a bank must continue to meet the interest payments to its subordinated debt holders if it is to remain in operation. Moreover, the holders of limited-life preferred stock and subordinated debt instruments must be paid when those debt instruments mature.

The amount of capital available per se does not provide useful information to regulators; capital must be measured relative either to some bank size factor (after all, larger banks are likely to have more capital than smaller banks, other things equal) of to the balance sheet items whose fluctuations bank capital is intended to cushion. Regulators are generally concerned with the amount of primary and total capital relative to some measure of the bank's total assets.

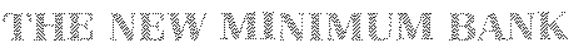

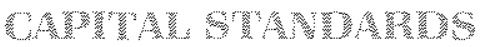

Under the new standards, the three federal agencies use both primary and total capital ratios in assessing the adequacy of a bank ${ }^{+}$s capital. The primary capital ratio is the ratio of primary capital to adjusted total assets; the total capital ratio is the ratio of total capital to adjusted total assets. The primary and total capital figures used are end of -quarter values, Adjusted total assets equal the average total assets held by banks over the previous three months, plus end-of-quarter values for reserves for loan and lease losses, minus those intangible assets not allowed for capital adecuacy purposes. The new minimum primary capital atio is 5.5 percent. This represents an increase in the minimum primary capital ratio of 0.5 percent for all FDICregulated banks and for OCC- and FED-regulated banks that have more than $\$ 1$ billion in assets; it represents a 0.5 percent reduction for OCC- and FEDregulated banks with assets less than $\$ 1$ billion. A brief discussion of the prior formally announced capital standards is contained in the insert on page 15 . 


\section{Table 1}

\section{Components of Bank Capital As Measured by the Federal Bank Regulatory Agencies}

tem

Description

\section{PAIMARY CAPITAL MEASURE}

a
a







equity

caplat$$
\text { common stock }
$$

perpetual preferted stock

surplus

undivided profits

capital reserves

Plus: mandatory convertible instruments

reserves for loan and lease losses

minority interest in consolidated subsidtaries

Minus: equity commitment notes

intangible assets
Aggregate par or stated value of outstanding common stock

Aggregate par or stated value of outstanding perpetual preferred stock Preferred stock is a form of ownership interest in a bank or other company which entitles its holders to some preference or priorty over the owners of common stock, usually with respect to dividends or asset distributions in a liquidation. Perpetual preferred stock does not have a stated maturity date and cannot be tedeemed at the option of the holder it includes those issues that are autonatically converted into common stock at a stated date

Amount received trom the sale of common or perpetual prefered stock in excess of its par or stated value.

Accumulated dollar value of profits after taxes that have not been distributed to shareholders of common and preferred stock as dividends.

Contingency and other captal reserves Reserves for contingencies include amounts set aside for possible unforeseen or indeterminate liabilites not othenwise reflected on the bank's books and not covered by insurance. Capital reserves include amounts sel aside for cash dividends on common and preferred stock not yet declared and amounts allocated for retirement of limited iffe preferred stock and debentures subordinated to deposits.

Debt issues that mandate conversion to common or perpetual preferted stock at some future date; they must meet the following conditions to be neluded in primary capital:

1. The securitjes must mature (convert to common or preferred stock) in 12 years or less.

2. The aggregate amount of mandatory convertible securites counted as primary capital may not exceed 20 percent of primary capital net of mandatony convertible securities.

3. The issuer may redeem the secunties before maturity only with the proceeds of the sale of common or perpetual preferred stock.

4. The holder of the security cannot accelerate the payment of principal except in the event of bankruptcy, insolvency or reorganization.

5. The security must be subordinated in right of payment to all senior indebtedness of the issuer.

Amount set aside to absorb anticipated losses Al charge offs of loans and leases are charged to this capital account, and recoveries on loans and leases previously charged off are credited to this capital account

The sum of the equify capital of the subsidtaries in which the bank has minority interest multipled by the percentage ownership of the bank in the subsidiaries.

Debt obligations which the issuer must repay only from the proceeds of the sale of common or perpetual preferred stock. These notes are included in mandatory convertible instruments, but excluded from primary capital.

Generally these assets represent the purchase price of firms that have been acquired in excess of their book value. 
Table 1 (Continued)

\begin{tabular}{|c|c|c|}
\hline & Item & Description \\
\hline \multicolumn{3}{|c|}{ SECONDARY CAPITAL MEASURE } \\
\hline \multirow[t]{2}{*}{ Pus: } & subordinated notes and debentures & $\begin{array}{l}\text { Debt obligations of issuer, with fixed maturity dates, that are subordinated to } \\
\text { depositors in case of insolvency Subordinated notes and debentures issued by } \\
\text { depository instifutions are not insured by the federal depost insurance agencies }\end{array}$ \\
\hline & $\begin{array}{l}\text { mandatory convertble instruments not } \\
\text { alloble for primary capital s }\end{array}$ & See mandatory convertible instruments definition above. \\
\hline
\end{tabular}

Tonly up to 20 percent of primany captal excluding mandatony convertible instruments.

The FDIC and oCC subtract all ntanglble assets except for purchased mortgage servicing nghts The FED subtracts only the goodwil potion of ntangible assets.

The limited life preferred stock and subordinated notes and debentures included n secondany capital must have an onginal weighted average maturity of atleast seven years All three federal banking agencies limit the aggregate amount of secondary capital to less than 50 percent of the amount of a banks primary capital.

The amount that exceeds 20 percent of primary capital excluding mandatory convertible instruments; equily commitment notes excluded Tomprimary captal

\section{A Brief History of Capital Adequacy Standards}

Before December 1981 , there were no uniform policies on capital adequacy among the three federal bank regulators. Minimum capital require ments applied only to the minimum dollar amounts of capital necessary for new banks None of the regulators had formally stated minimum. requirements for the ratio of total capital to total assets Instead, each regulator typically compared capital ratios for banks grouped together by common characteristics, including asset size, and attempted to persuade those banks that had relatively low capital ratios to raise them

In December 1981 , the three federal banking agencies announced minimum primary capital ratos for the banking organizations that they regulate The FDlC set its minimum primary capital standard at 5 percent The OCC and the FED adopted primary capital standards of 5 percent for banks and bank holding companies with total as sets of $\$ 1$ billon or more (called regional banks) and 6 percent for smaller banks and bank holding companes (called community banks). This dichot- omous capital standard largely reflected the actual differences in average capital ratios that existed when the standards were adopted. No minimum capital ratios were established at that time for the 17 largest banking organizations termed multinationals, Instead their capital adequacy as judged by the appropriate regulatory agency, depended on the unique characteristics of each organization.

The $O C C$ and the FED also announced total capital standards at this time for regional and community banking organizations. A regional bank was considered under-capitalized if its total capital ratio was less than 5.5 percent, marginally capitalized if it ranged between 5.5 and 6.5 percent, and adequately capitalized if it exceeded 6.5 percent; the total capital standards for community banks were 0.5 percent higher for each category. .

In June 1983, the FED and the OCC specified minimum capital standards for the 17 multinational banking organizations that were identical to those previously announced for regional banks. 


\section{Table 2}

Capital, Assets and Capital Ratios for U.S. Commercial Banks:

\section{December 31, 1984, Report of Condition}

\begin{tabular}{|c|c|c|c|c|c|c|c|c|}
\hline & \multirow{2}{*}{$\begin{array}{l}\text { number } \\
\text { ort } \\
\text { Gans }\end{array}$} & \multicolumn{2}{|c|}{$\begin{array}{l}\text { capital } \\
\text { (bilions } \\
\text { of collars) }\end{array}$} & \multirow{2}{*}{$\begin{array}{l}\text { Assets } \\
\text { (bilions } \\
\text { of dollars) } \\
\text { Total }\end{array}$} & \multicolumn{2}{|c|}{$\begin{array}{l}\text { Average } \\
\text { Capital hatios }\end{array}$} & \multicolumn{2}{|c|}{$\begin{array}{l}\text { Aggregate } \\
\text { Capital Ratios }\end{array}$} \\
\hline & & Prinary & Total & & Primary & Total & Pitmany & Total \\
\hline All U s Commercial Banks & 14,404 & $\$ 1743$ & $\$ 180.1$ & $\$ 2,443,3$ & $11.0 \%$ & $11.0 \%$ & $7 \%$ & $74 \%$ \\
\hline By Asset Size? & & & & & & & & \\
\hline Less har s25 nillion & 5.501 & 8.3 & 8.4 & 780 & 145 & $1,4.5$ & 106 & 108 \\
\hline S25 nillon lo s300 nullion & 8,62 & 49.8 & 50.5 & 5800.6 & 8.9 & 90 & 85 & 87 \\
\hline S300 nulion lo sh Silion & 466 & 178 & 18.3 & 2322 & 77 & 79 & 17 & 79 \\
\hline 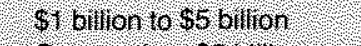 & 209 & 283 & 296 & 4134 & 69 & 72 & 68 & 72 \\
\hline Grearer than 85 bilion & 66 . & $70 \%$ & 783 & 1,1800 & 6.4 & 67 & 62 & 66 \\
\hline
\end{tabular}

The new minimum ratio for total capital is 6 percent of adjusted total assets. The FED continues to use "zones" for total capital ratios; however, it has eliminated the differences that previously existed between the smaller and larger banks. The FED considers banks to be "under-capitalized" if their total capital ratios are less than 6 percent, "marginally capitalized" if their total capital ratios lie between 6 and 7 percent, and "adequately capitalized" if their total capital ra" tios exceed 7 percent. These changes affect only the larger banking organizations with assets exceeding \$1 billion; smaller banking organizations already were stabject to these standards.

These new standards for capital adequacy represent minimum capital ratios for all commercial banks. The federal banking regulators will require specific banks to meet higher capital ratios if they have high off-balance-sheet exposure or if their assets are considered to be relatively risky - that is, to have relatively high probability of significant declines in value?

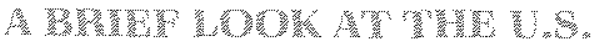

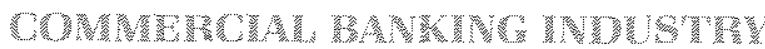

Before describing the impact of the new capital standards on the U.S, commercial banking industry, it is first necessary to describe the industry itself in brief detail. The latest statistics covering the capital, assets and capital-asset ratios for U.S. commercial banks are shown in table 2 . There are several key points that will prove useful when assessing the impact of the new

'For one recent FDIC directive for greater-than-minimum capital ratios, see Luke (1985). capital standards on individual banks and the banking industry.

First, for the banking industry as a whole, the primary and total capital ratios are well above the minimum standards established by the bank regulatory agencies. The average primary capital ratio (that is, the sum of the individual banks' primary capital ratios divided by the number of banks) for the 14,404 banks is 11 percent; the average total capital ratio is also 11 percent. An alternative way to assess the capital adequacy of the banking system is to divide the total amount of capital (primary or total capital) of all banks by the total quantity of adjusted total assets of all banks. This global view of capital adequacy yields the aggregate capital ratios shown in the last two columns of table 2. Although these aggregate capital ratios 17.1 percent for primary capital and 7.4 percent for total capital for the entire banking system are considerably lower than the banks' average capital ratios, they are still comfortably above the new minimum capital adequacy standards.

The reason for the large disparity between the average and aggregate capital ratios for banks is clearly discernible when the banks are divided into the selected asset-size categories shown in table 2. The distribution of the banking system's capital and assets is highly skewed among the 14,404 U.S. commercial banks. The 66 largest banks hold about 41 percent of total capital and 46 percent of the total assets of the U.S. banking system; they also have the lowest average capital ratios. In contrast, the 13,663 banks $(95$ percent of the total number of banks) in the two smallest assetsize categories hold only about 33 percent of the capital and 27 percent of the total assets of the banking 
system; these small banks have the highest average capital ratios.

The broad conclusion that emerges from the data in table 2 is that the new capital standards seem unlikely to produce substantial changes in the U.S. banking industry as a whole. The average and aggregate capital ratios exceed the new minimum standards by wide margins. However, the data suggest that, since capital ratios decline as bank size increases, larger banks are likely to be affected by these standards to a greater degree than the smaller banks.

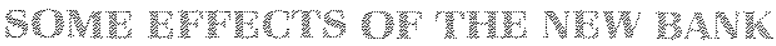

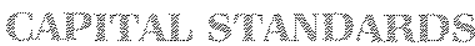

Bank data from the December 31, 1984, Report of Condition for U.S. commercial banks were used to assess the impacts that the new standards would have had if they had been in effect at that time. Of the 14,404 banks analyzed, only $\mathbf{4 1 9}$ had capital ratios that fell below the new standards. Selected statistics for these capital-deficient banks are presented in table 3 .

The 419 capital-deficient banks hold about 14 percent of the capital and 18 percent of the assets of the entire banking system. While only 3 percent of all banks do not meet the new standards, about 13 percent of the banks with assets of $\$ 1$ billion to $\$ 5$ billion and more than 21 percent of the banks in the largest asset size category are capital-deficient. Moreover, the 14 largest capital-deficient banks hold about 78 percent of the capital and assets of all deficient banks as a group.

There are several ways that capital-deficient banks can bring their capital ratios into line with the minimum standards specified by the bank regulators. Two such methods are considered in the last four columns of table 3. The purpose of these calculations is to present some estimates of the magnitude of the adjustments to capital or liabilities that these banks face in achieving the minimum capital standards.

One way in which capital-deficient banks can raise their capital ratios would be to increase their capital (and assets). These adjustments could involve selling new shares, retaining a greater amount of earnings or selling existing assets that have been carried on their books at below-market values. "These adjustments would increase both capital and assets by equal

${ }^{8}$ For recent results of such sales, see Thompson, Wilson and Frank (1984) and Advertisement (1985). amounts, leaving liabilities unchanged. The increases in bank capital necessary to achieve the new minimum standards are shown in the next -to-last column of table 3 . The required additions to total capital are divided into the minimum amounts of primary capital and the maximum amounts of secondary capital that would be consistent with provisions of the new capital requirements on the composition of total capital.

To bring their capital ratios up to the minimum standards, the capital-deficient banks would have to raise slightly less than $\$ 1.8$ billion. This represents only a 1 percent increase in the capital of the entire banking industry and about a 7.4 percent increase in the capital of the deficient banks. The 14 largest deficient banks would have to raise the lion's share of this additional capital - nearly $\$ 1.1$ billion.

Although the larger banks face the largest prospective dollar increases in capital, the relative magnitudes of the increases are greater for the smaller banks with deficient capital. The largest deficient banks would have to increase their total capital by about 6 percent. For deficient banks in the smallest size class, however, the necessary increase is about 23 percent.

There is growing interest in the use of secondary capital sources for raising new capital ${ }^{3}$ Many banks may consider issuance of debt instruments to be a less costly way of raising capital than selling stock. Banks avoid diluting the shares of existing stockholders when they issue debt instruments. This option, however, is available primarily to the 14 largest deficient banks, which could raise up to 83 percent of the capital they need from secondary sources." In contrast, the remaining 405 capital-deficient banks must use primary capital sources for at least 71 percent of the capital they need."

The last column in table 3 shows what the deficient banks would have to do if they chose to raise their capital ratios by shrinking their assets and liabilities, while holding their capital unchanged. If these assets were sold to nonbank firms, the banking industry's assets would decline by $\$ 28$ billion, or slightly more than 1 percent: the assets of the deficient banks would

\footnotetext{
4For discussions of the use of subordinated debt to meet the new capital standards, see Horvitz (\$984), Rose (1985) and Childs (1985).

10This analysis applies only to the primary and secondary capital of commercial banks. If banking organizations adjust to the new capital requirements by issuing more capital securities, most of those capital securities sold to the nonbank public will be issued by the holding companies that own the banks with deficient capital.

"Some analysts have questioned the ability of smaller banks to use secondary capital sources; see, for example, Ostrowski (1985).
} 
decline by about 6.6 percent. Again, as noted above, the 14 largest banks would bear the largest share of the asset reductions - over 60 percent.

Several general conclusions emerge from the data in tables 2 and 3 . The new minimum capital standards will affect only a small proportion of all U.S. commercial banks - slightly less than 3 percent. For the industry as a whole, the standards can be met by relatively minor percentage increases in capital or reductions in assets and liabilities. The 419 deficient banks would have to raise nearly $\$ 1.8$ billion in new capital to satisfy the minimum standards; alternatively, they could reduce their assets and liabilities by $\$ 28$ billion. Either approach would result in changes of about 7 percent in their capital or asset holdings, respectively. The bulk of these capital or asset adjustments, however, is concentrated in the 14 largest capital-deficient banks, which would have to raise about $\$ 1,1$ billion in new capital or reduce their assets and liabilities by nearly $\$ 17$ billion.

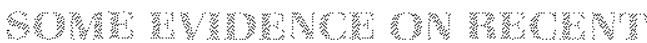

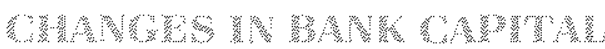

Banks have raised their capital substantially in re cent years. The remaining increase in capital necessary to meet the new requirements is small relative to these recent capital increases. One recently published survey reported that U. S. commercial banks raised $\$ 10.2$ billion in 1983 and $\$ 12.5$ billion in 1984 via stock or debt financing; banks with assets of more than $\$ 5$ billion raised nearly $\$ 12$ billion (96 percent of the total capital raised by all banks) in $19844^{12}$ The OCC estimates that, over the three-year period ending on December 31, 1983, national banks added about $\$ 2.3$ billion per year to their capital accounts from retained earnings and additions to loan loss reserves alone. ${ }^{13}$

The impact of the recent changes in bank capital in terms of capital adequacy under the new standards can be estimated by applying the new capital standards to the March 31, 1984, Report of Condition data and measuring the changes in bank capital land potential bank capital deficiencies that have occurred from March 31 to December 31, $1984 .{ }^{14}$ When analyzed

12See "Banks' Financings Rose. ." (1985). These capital issues were primarily sold by the bank holding companies, not by individual subsidiary banks.

15See Federal Register (1985).

14The Report of Condition for March 31,1984 , is the first to include the information necessary to calculate the capital ratios as measured under the new standard for capital adequacy. in this fashion, $\mathcal{U}$. S commercial banks raised their total capital by $\$ 16.3$ billion from the end of March to the end of December 1984; in so doing, the number of potentially capital-deficient banks fell from 501 to 419 .

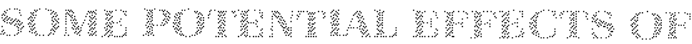

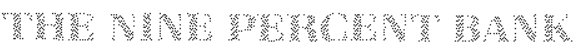

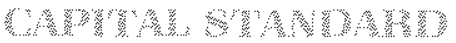

There have been suggestions recently that even higher bank capital standards might be desirable.:" One prospective standard that has received considerable attention lately has been the "nine percent capital solution": a total capital standard of nine percent, with primary capital equal to at least six percent of adjusted total assets. ${ }^{16}$ The results of applying this standard to U.S. commercial banks, using the December 31 , 1984, Report of Condition, are shown in table 4.

The nine percent capital standard would significantly affect the banking system if it were to be adopted in the near future. More than half of all banks currently would fail to meet this standard. Moreover. the deficient banks hold about 80 percent of the banking system's capital and about 87 percent of its assets. The basic problem facing the industry is that the nine percent standard greatly exceeds the banking system's present capital-asset structure. As was noted earlier (see table 2 ), the aggregate total capital ratio for the entire banking industry is only 7.4 percent, well below the 9 percent level.

The additional capital that would be needed to meet the nine percent standard, as shown in table 4 , is about $\$ 52$ billion. This represents a 29 percent increase from the present industry level; almost 95 percent of the increase, however, could be met from secondary capital sources.

To put this figure into perspective, we noted earlier that the banking system increased fotal capital by about $\$ 16$ billion from March to December of last year. It would take about two and one-half years of similar

sfor example, Sen. Willam Proxmire recently suggested that banks should be required to meet a 10 percent capital requirement. See Bureau of National Affairs (1985).

${ }^{16}$ A suggestion for a capital standard of 9 to 11 percent was included in a recent study by the Administration's Cabinet Council on Economic Affairs Working Group on Financial institutions Reform. See Department of the Treasury (1985). On May 6,1985 , the Board of Directors of the FDIC requested public comment on the 9 percent total capital requirement for all FDIC-insured banks. For comments on the higher capital standards, see Noble (1985) and Wallace and Reimer (1985). 
Table 3

Analysis of U.S. Commercial Banks That Do Not Meet the New Capital Standards:

December 31, 1984, Report of Condition

\begin{tabular}{|c|c|c|c|c|c|c|c|c|c|c|}
\hline . & \multirow{2}{*}{\multicolumn{2}{|c|}{$\begin{array}{l}\text { Number of Banks } \\
\text { Deficient In }\end{array}$}} & \multirow{3}{*}{$\begin{array}{l}\text { Total } \\
\text { Number } \\
\text { of Deficient } \\
\text { Banks }\end{array}$} & \multirow{2}{*}{\multicolumn{2}{|c|}{$\begin{array}{l}\text { Capital } \\
\text { (millions } \\
\text { of dollars) }\end{array}$}} & \multirow{3}{*}{$\begin{array}{l}\text { Assets } \\
\text { (millions, } \\
\text { of dollars) } \\
\text { Total }\end{array}$} & \multicolumn{3}{|c|}{$\begin{array}{l}\text { Increase in Capital } \\
\text { Needed To Achieve } \\
\text { New Standards } \\
\text { (millions of dollars) }\end{array}$} & \multirow{3}{*}{$\begin{array}{l}\text { Decrease } \\
\text { n Assets } \\
\text { Needed } \\
\text { to Achieve } \\
\text { New } \\
\text { Standards } \\
\text { (millons } \\
\text { of } \\
\text { dollars) }\end{array}$} \\
\hline & & & & & & & Mnimum & Maximum & & \\
\hline & $\begin{array}{l}\text { Primary } \\
\text { Capital }\end{array}$ & $\begin{array}{l}\text { Total } \\
\text { Capital }\end{array}$ & & Primary & Total & & Capital & Capital & Total & \\
\hline All Banks & 242 & 398 & 419 & $\$ 237678$ & $\$ 24,3198$ & $\$ 430,448.0$ & $\$ 676$. & $\$ 1,1+4,2$ & $\$ 1,790,3$ & $\$ 28,4775$ \\
\hline \multicolumn{11}{|l|}{ By-Asset Size: } \\
\hline Less than $\$ 25$ million & 63 & 105 & 108 & 812 & 834 & 1,6714 & 13.8 & 54 & 192 & 3060 \\
\hline$\$ 25$ million to $\$ 300$ million & 141 & 223 & $233:$ & 946.0 & 9687 & 18,8491 & 1193 & 63.2 & 1825 & 29297 \\
\hline$\$ 300$ million to $\$ 1$ billion & 17 & 34 & 36 & 9431 & 9916 & 182435 & 936 & 438 & 137.4 & 22000 \\
\hline$\$ 1$ billion to $\$ 5$ billion & 16 & 24 & 28 & 2,9778 & 3,1836 & 57,1287 & 2643 & 916 & 3558 & $5,799.3$ \\
\hline Greater than $\$ 5$ billion & 5 & 12 & 44 & 18,8197 & 190616 & 3345550 & 1852 & 9102 & 1,0954 & 172425 \\
\hline
\end{tabular}

Table 4

Analysis of Deficient U.S. Commercial Banks Under the Proposed Nine Percent Capital Standard: December 31, 1984, Report of Condition

\begin{tabular}{|c|c|c|c|c|c|c|c|c|c|c|}
\hline & \multicolumn{2}{|c|}{$\begin{array}{c}\text { Number of Banks } \\
\text { Deficient in }\end{array}$} & \multirow{3}{*}{$\begin{array}{c}\text { Total } \\
\text { Number } \\
\text { of Deficient } \\
\text { Banks }\end{array}$} & & & \multirow{3}{*}{$\begin{array}{l}\text { Assets } \\
\text { (millions } \\
\text { of dollars) } \\
\text { Total }\end{array}$} & \multicolumn{3}{|c|}{$\begin{array}{l}\text { ncrease in Capital } \\
\text { Needed To Achieve } \\
\text { Nine Percent Standard } \\
\text { (miltions of dollars) }\end{array}$} & \multirow{3}{*}{$\begin{array}{l}\text { Decrease } \\
\text { in Assets } \\
\text { Necessary } \\
\text { to Achieve } \\
\text { Nine } \\
\text { Percent } \\
\text { Standard } \\
\text { (millions } \\
\text { of doliars) }\end{array}$} \\
\hline & \multirow{2}{*}{$\begin{array}{l}\text { Primary } \\
\text { Capital }\end{array}$} & \multirow{2}{*}{$\begin{array}{c}\text { Total } \\
\text { Capital }\end{array}$} & & of do & lars) & & $\begin{array}{l}\text { Minimum } \\
\text { Primary }\end{array}$ & Maximum & & \\
\hline & & & & Primary & Total & & Capital & Capital & Total & \\
\hline All Banks & 498 & 7,668 & 7,668 & $\$ 138,155.0$ & $\$ 143,2750$ & $\$ 2,114,8760$ & $\$ 2,752,1$ & $\$ 48,951.8$ & $\$ 51,704,0$ & $\$ 522,935.0$ \\
\hline \multicolumn{11}{|l|}{ By Asset Size: } \\
\hline Less than $\$ 25$ million & 115 & 2,089 & 2,089 & $2,520,7$ & 2,5334 & $32,771,4$ & 20.4 & 436.7 & 457.0 & 4,6220 \\
\hline$\$ 25$ million to $\$ 300$ million & 266 & 4,938 & 4,938 & 28,9469 & $29,413,1$ & 388,8700 & 201.6 & $5,931.7$ & $6,133.3$ & $62,057.7$ \\
\hline$\$ 300$ million to $\$ 1$ billion & 48 & 387 & 387 & 13,6359 & 14,0497 & 194,8420 & 172.1 & $3,654,4$ & $3,826.5$ & $38,734,7$ \\
\hline$\$ 1$ billion to $\$ 5$ billion & 40 & 190 & 190 & 24,9519 & 26,0212 & 379.4950 & 518.3 & $8,413.3$ & $8,931,6$ & $90,370,3$ \\
\hline Greater than $\$ 5$ biltion & 29 & 64 & 64 & $68,099.1$ & 71,2572 & $1,118,8970$ & $1,839.8$ & $30,515.8$ & $32,355.5$ & $327,150,0$ \\
\hline
\end{tabular}


increases, while keeping liabilities unchanged, for the banking system to adjust to the nine percent capital standard.

Because the capital ratios generally decline as bank size increases (table 2), the largest banks would have to raise the biggest percentage of the total capital needed. In the largest size category, 64 (of 66) banks would be deficient; they would have to raise more than $\$ 32.4$ billion in new capital, an increase of 44 percent. In contrast, only about 38 percent of the banks in the smallest asset size category would be deficient; the $\$ 457$ million they would have to maise represents only a 5 percent increase in their capital.

The last column in table 4 shows that, if banks leave their capital unchanged, they would have to reduce their assets and liabilities by about $\$ 523$ billion. In other words, the banking industry would shrink by more than 21 percent. The 64 largest deficient banks would have to reduce their assets by nearly 29 percent (\$327 billion).

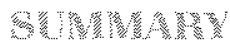

The U.S. banking industry can meet the new capital standards recently announced by the nation's three federal banking regulatory agencies with relatively small changes in capital or assets. As of December 31 , 1984, slightly less than 3 percent of all U.S. commercial banks did not meet the minimum capital standards for all commercial banks recently adopted by the Federal Deposit Insurance Corporation, the Federal Reserve and the Office of the Comptroller of the Currency. Deficient banks can meet these standards by raising about $\$ 1,8$ billion in new capital or reducing their assets (and liabilities) by stightly more than $\$ 28$ billion. Neither of these altematives (nor some combination of these changes that would achieve the same result represent significant changes in the capital/ asset structure of the banking system; the necessary changes in assets and liabilities or capital represent only about 1 percent of the amounts held by U.S. commercial banks.

On the other hand, the 9 percent total capital standard that has been recently proposed would require considerable adjustment by the banking system if it were imposed in the near future. The capital ratios of more than half of all banks currently fall below the 9 percent standard; indeed, in the aggregate, the U.S. banking system's total capital ratio is only slightly above 7 percent. To meet the 9 percent capital standard, deficient banks would have to raise about $\$ 52$ billion in new capital or reduce their assets and liabilities by about $\$ 523$ billion. Thus, either U.S. bank capital would have to rise by nearly 29 percent, or the assets of the US. banking industry would have to shrink by more than one-fifth.

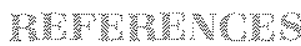

Advertisement. "Raising Over $\$ \uparrow$ Billion of Capital For Commercial Banks in 1984 Fhrough The Sale of Real Estate," Wall Street Journal, January $30,1985$.

"Agricutture: FDlC Study Says Farm Bank Failures Largely Due to Mismanagement." Daily Report for Executives, DER 56. Bureau of National Affairs, March 22, 1985, P. L-5.

"Bank Crisis Tied to Drop In Confidence." New York Journal of Commerce, April 8, 1985.

"Banking Confidence May Emerge as a Potent Poltical Issue." Wall Street Joumal, April 12, 1985

"Banking: Proxmire Recommends Raising Bank Capital Levels." Daily Report for Executives, DER No. 63, Bureau of National Affairs, April 2, 1985, p. A-9.

"Banks' Financings Rose $22.8 \%$ in ' 84 to Record Amount." Wall Street Journal, April 8, 1985.

Belsie, Laurent. "Troubled times for farmers will weed out the rural banks," Christian Science Monitor, April 10, 1985.

Bundell, William E. "As Basic institutions Like Phones and Banks Change, Public Chafes," Wall Street Journal, February 5, 1985.

Childs, John F. Letter to the Editor, American Banker, January 18 , 1985.

Department of the Treasury. "Deposit Insurance Study Forwarded to CCEA," Treasury News, January 15, 1985.

Federal Deposit Insurance Corporation. "Deposit Insurance in a Changing Environment." in A Report to Congress on Federal Deposit insurance, Appendix B (April 15, 1983).

Federal Register. Vol. 50, No. 50 (March 14, 1985), p. 10, 212.

Gross, Laura. "Consumer Confidence in Banking Down," American Banker, October 20, 1984.

Horvitz, Pau M. "Subordinated Debt is Key To New Bank Capital Requirements," American Banker, December 31, 1984.

Luke, Robert. "New Valencia Bancorp Chief Cuts Staff, Restructures Management, Sells Assets," American Banker, April 10, 1985.

"More Bank Failures to Come." The Economist (March 23, 1985).

Noble, Kenneth B. "New Capital Suggested To Make Banks Safer," Now York Times, January $11,1985$.

Office of the Comptroller of the Currency. Final Regulatory impact Analysis (1985).

Ostrowski, Peter. "Higher Capital Rules Would Be a Blow to Banking's Little Guys." American Banker, March 15, 1985.

Rose, Sanford. "Aandom Thoughts," American Banker, January 18 and January $3 \uparrow, 1985$.

Thompson, Terri, John W. Wiison, and John Frank, "Banks Start Selling Their Place In the Skyline," Business Week (December 17, 1984).

Wallace, G. David, and Blanca Riemer. "More Capital For Banks: The Cure May Be Worse Than The Disease," Business Week (January 28, 1985). 